\title{
Using visual stimuli to explore the social perceptions of ecosystem services in cultural landscapes: the case of transhumance in Mediterranean Spain
}

\author{
$\underline{\text { César A. López-Santiago }}{ }^{1}, \underline{\text { Elisa Oteros-Rozas }}{ }^{1}, \underline{\text { Berta Martín-López }}^{1}, \underline{\text { Tobias Plieninger }}^{2}, \underline{\text { Esther González Martín }}^{1}$ and $^{\text {José A. }}$ \\ González $^{1}$
}

\begin{abstract}
The ecosystem services approach has been proposed as a powerful tool for the analysis of coupled social-ecological systems. This approach is particularly useful for the evaluation of cultural landscapes, which represent the joint evolution of humans and nature across an extended time span. Transhumance is a customary practice of mobile pastoralism, involving the regular seasonal migration of livestock herds between summer and winter pasturelands. This practice maintains unique cultural landscapes in Mediterranean Spain, which have been shaped over many centuries of pastoral activity. Drove roads, which are used for herd migration, represent the most outstanding feature of these landscapes. We used visually based landscape interpretation to evaluate social perceptions of ecosystem services provided by the Conquense Drove Road transhumance landscape in Spain. Face-to-face questionnaires $(\mathrm{N}=$ 314) were given to a sample of local inhabitants, visitors, and urban inhabitants. The questionnaires contained two pairs of photographs depicting images of croplands and pine forests associated with the transhumance landscape, with one photograph in each pair containing a drove road. We compared the social perceptions of 16 ecosystem services supplied by these two landscapes. These 16 services were divided into 3 types: provisioning, such as the production of food and water; regulating, such as the control of climate and disease; and cultural, such as spiritual and recreational benefits. We also identified differences between landscapes with and without a drove road. Overall, respondents recognized the higher capacity of forests to deliver a wider range of ecosystem services to society compared with croplands. Provisioning services were mostly associated with cropland, whereas regulating services and cultural ecosystem services tended to be related to forests. All three types of ecosystem services were more perceived by respondents when a drove road was present in each landscape. However, differences in the visual perception of ecosystem services supply and preference for transhumance landscapes emerged in relation to certain socio-demographic and cultural respondent characteristics such as a previous relationship with transhumance and agriculture, rural/urban origin and identity, environmental awareness, and cultural attachment to a place. Four groups of respondents had consistent and diverging ecosystem services appreciation, revealing various potential conflicts and tradeoffs. We discuss the applicability and usefulness of the proposed approach for evaluating ecosystem services in cultural landscapes and for informing policy-making processes.
\end{abstract}

Key Words: cropland; drove road; ecosystem services; Mediterranean landscapes; pine forest; transhumance; visual perception

\section{INTRODUCTION}

Acknowledging the close links between society and ecosystems is particularly critical when managing cultural landscapes that are the result of the joint evolution of humans and nature across an extended time span (Plieninger and Bieling 2013). Some authors have proposed that Mediterranean landscapes were designed by cultures (Blondel 2006) and that ecological structures and functions have been maintained for millennia by human actions through socio-cultural feedback mechanisms in this ecoregion (Farina 2000, Blondel et al. 2010). Therefore, a comprehensive analysis of the ecological, social, and economic dimensions of these coupled social-ecological systems is required to properly manage Mediterranean cultural landscapes (García-Llorente et al. 2012). It is necessary to understand how societies benefit from nature and why people value the contributions of ecosystems to human well-being (Martín-López et al. 2012).

The ecosystem services framework has been proposed as a powerful conceptual approach for such analysis and has received widespread attention from representatives of environmental policy and practice (Chan et al. 2006, 2011, Fisher et al. 2009). Scientists, managers, and practitioners have used this framework to foster communication with people living in and benefiting from landscapes and ecosystems. Because the framework focuses on the contributions of ecosystems to human well-being (de Groot et al. 2002, 2010), it has the potential to become an effective common social code for addressing stakeholder perceptions of landscape management options (Menzel and Teng 2010).

To date, ecosystem services research has mainly focused on biophysical analyses of the capability of ecosystems to deliver services and on the economic valuation of these services (Vihervaara et al. 2010, Nieto-Romero et al. 2014). However, there have been frequent warnings that insufficient attention is being given to the values, attitudes, and meanings that underlie the societal demand for ecosystem services (Lamarque et al. 2011). It has been argued that the importance of Mediterranean ecosystems for society is linked to certain values and preferences of individuals that extend beyond monetary estimations (MartínLópez et al. 2014) and that these values and preferences require incorporation into planning processes (Larson 2013). Hence, there is a clear need to develop alternative methods that take into account people's perceptions of ecosystem services, particularly in cultural landscapes. Existing socio-cultural valuation approaches have proven useful for acknowledging the diversity of values emerging from the ecosystem services spectrum and for providing information about the relationship between human well-being and ecological changes (Chan et al. 2012). Studies of cultural landscapes provide a useful conceptual nexus for the simultaneous analysis of both biophysical and psychosocial phenomena (Selman 2012), which are strongly linked in terms of their foundations and goals with the ecosystem services approach.

${ }^{1}$ Social-Ecological Systems Laboratory, Department of Ecology, Edificio de Biología, Universidad Autónoma de Madrid, Madrid, Spain,

${ }^{2}$ Department of Geosciences and Natural Resource Management, University of Copenhagen 
The combination of the two complementary paradigms, that is, ecosystem services approach and cultural landscapes, which are generally used by a broad array of scientific communities, could provide a window of opportunity to improve the effectiveness of environmental decision making (Schaich et al. 2010).

An important purpose of ecosystem services science is the identification of trade-offs, which are produced when the delivery, i.e., supply, or social use or value, i.e., demand, of one or multiple ecosystem services compromises other specific services (Raudsepp-Hearne et al. 2010). Although considerable research has been devoted to the analysis of trade-offs in the supply of ecosystem services (e.g., Chan et al. 2006, Raudsepp-Hearne et al. 2010), analysis of trade-offs in the demand for ecosystem services remains far less frequent. The trade-off resulting from different demands for ecosystem services is frequently because of the heterogeneous ecosystem service values perceived by different stakeholders (Martín-López et al. 2012). Analysis of the sociocultural preferences of different societal groups fosters awareness of these frequently neglected trade-offs in demands for ecosystem services and consequently provides information about the social dynamics surrounding ecosystem services. Through highlighting differing views and interests, such approaches allow identification of the winners and losers resulting from changes in provision of ecosystem services (Beymer-Farris et al. 2012).

People experience the landscape as a socially constructed phenomenon at the nexus between biophysical attributes, emotional meaning, and human actions (Tuan 1974). In addition, landscape is conceptualized as a product of the multisensory perception of interrelations among ecological components (González-Bernáldez 1981). The European Landscape Convention (Council of Europe 2000:3) defined a landscape as "an area as perceived by people, whose character is the result of the action and interaction of natural and human factors." Furthermore, some authors (Gobster et al. 2007, Fry et al. 2009) believe that humans engage with the environment through their experience of landscapes, with visual perception being a key process that connects humans with ecological phenomena. Most of the information that shapes our behavior and orients our biological adaptation to the environment is captured visually (Ornstein and Carstensen 1991). Because visually based landscape perception could be used as a socially shared communication channel, it is an ideal tool for investigating the human-ecosystem interface. For this reason, evidence based on visual stimuli has been long used in perception-based methods of landscape research (e.g., Daniel 2001).

Several studies have highlighted the utility of visual stimuli as a reliable and consistent means for exploring the attitude of people toward ecosystems, either for qualitative and phenomenological purposes (Carlsson 2001, Beilin 2005, Berbes-Blazquez 2012) or for more quantitative or positivistic goals (Daniel 2001), with comprehensive examples in the Mediterranean context (DeLucio and Múgica 1994, Arriaza et al. 2004, Surová and Pinto-Correia 2008). Both approaches complement each other and are based on the assumption that images, a nonverbal medium, are more effective at evoking landscape perceptions than spoken or written words (Harper 2002). However, as far as we know, perceptionbased methods have not been previously used to evaluate people's awareness of ecosystem services associated with particular cultural landscapes. We hypothesized that people are able to identify the ecosystem services that they appreciate for a given landscape when pictures are presented as visual stimuli, using the pastoral landscapes of Mediterranean Spain as a case study.

Our specific objectives were to (1) compare perceptions of ecosystem services using two different cultural landscapes as visual stimuli, a pine forest and a cropland; (2) explore the visual perception of ecosystem services delivered by landscapes with and without a drove road as a mean of assessing the perceived importance of migrant livestock movements (transhumance) in cultural landscapes for different types of people; and (3) analyze the association of the appreciation of ecosystem services with the socio-demographic and cultural characteristics of respondents, and uncover possible emerging trade-offs.

\section{STUDY AREA AND METHODS}

\section{The transhumance landscape of the Conquense Drove Road}

Transhumance is a customary pastoral practice that comprises regular seasonal migrations of livestock herds between summer pastures in the highlands, usually located at northerly latitudes and winter pastures in the lowlands, usually located at southerly latitudes. This practice aims to match grazing pressure with seasonal peaks in pasture availability (Ruiz and Ruiz 1986). The summer and winter pastures are connected by drove roads, which are the most outstanding landscape feature of transhumance. A network of Royal Drove Roads (cañadas reales, $75 \mathrm{~m}$ wide) and smaller drove roads (cordeles, veredas) crosses Spain. The whole network extends over roughly $125,000 \mathrm{~km}$ and was granted legal protection through a Drove Roads Act in 1995 (Merino and Alier 2004).

Our research was conducted on the Conquense Drove Road, one of the longest drove roads still used by Spanish herders to move cattle and sheep on foot (Fig. 1). It is a corridor approximately $410 \mathrm{~km}$ long that crosses a mosaic of agroecosystems composed of vineyards, sunflowers, cereals, olive groves, and some remnants of Mediterranean oak forest (Quercus ilex) in La Mancha (Cuenca and Ciudad Real provinces) and pine forests (Pinus sylvestris) in La Serranía de Cuenca (Cuenca province). The study area encompassed the whole of the Conquense Drove Road, along with all of the landscapes and communities that it intersects. Based on official livestock-movement permits, a total of 87 shepherds currently practice transhumance in the study area. Although most of the shepherds now use trucks to move their livestock, 15 herders still walk the drove road every year with almost 9000 sheep and 1200 cows (Oteros-Rozas et al. 2012a).

The cultural landscapes of transhumance (Herzog et al. 2005) have been shaped over many centuries through the adaptation of pastoral practices to a harsh and highly fluctuating environment. These landscapes are widely acknowledged as providing important ecosystem services such as fire prevention, maintenance of soil fertility, landscape connectivity and habitat for species, traditional ecological knowledge, cultural identity, food, and genetic resources (Bunce et al. 2004, Oteros-Rozas et al. 2012b).

\section{Data collection}

Data were obtained in the form of standardized questionnaires from August to November 2010. Face-to-face interviews were 
Fig. 1. Map of the study area with the Conquense Drove Road (green) and the associated summering (yellow) and wintering (blue) areas. The two pairs of images used for exploring social perception of ecosystem services: forest landscape without the drove road (A), forest landscape with the drove road (B), cropland landscape without the drove road (C), and cropland landscape with the drove road (D).
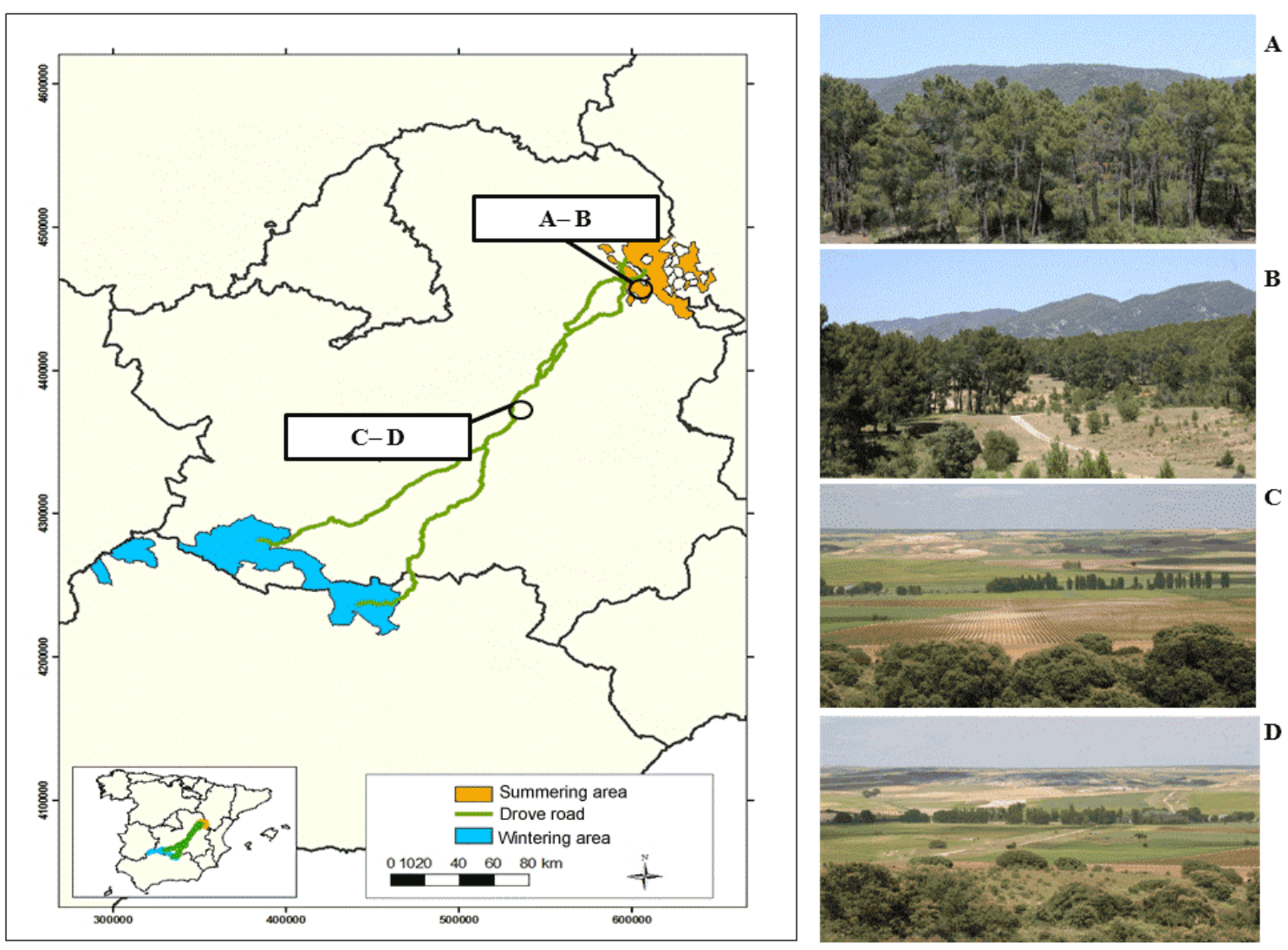

conducted with individuals older than 18 years of age who inhabited the 23 municipalities of the study area and the city of Madrid. Respondents were surveyed in public locations such as market places, recreation areas, restaurants, and local municipality offices. The interviewees were selected according to a "theoretical sampling strategy," which fits well with samples that are not fully representative statistically, but rather are selected in search of a maximum variety of opinions (Patton 1990). Our goal was to get a theoretical sample made of as many differing opinions as possible and to represent the margin of the sampling universe in a context of limited economic and human resources for research. Perception-based methods have high internal reliability even among relatively small groups (see Daniel 2001 for further discussion of this topic).

The questionnaire was designed using information from a previous study (Oteros-Rozas et al. 2012b), particularly regarding the selection of the respondents and ecosystem services being evaluated. The survey was pretested on a small sample population $(\mathrm{N}=25)$ before being administered to the final sample. Fewer than $20 \%$ of people refused to participate, with just 10 questionnaires being left incomplete. Those were removed from the final sample.
The final sample consisted of 314 complete questionnaires (see Appendix 1 for more details about sample characteristics). Both local $(\mathrm{N}=191)$ and nonlocal $(\mathrm{N}=123)$ people were surveyed to compare the effects of personal links with the cultural landscapes. Locals were considered to be people closely related to the study area, including practitioners of transhumance, farmers, and locals from other professions. Nonlocals included people such as visitors not directly linked to the study area, along with a reference group of environmental science scholars and students in their final year of their undergraduate degree. Considering the total population of the study area, 167,558 inhabitants in the municipalities of the Conquense Drove Road network, the sampling error was estimated as $\pm 5.95 \%$ for locals and $\pm 7.42 \%$ for nonlocals, at the confidence level of $90 \%$.

The questionnaire was designed to assess the visual perception of ecosystem services in a given landscape using original, not manipulated, photographs (see Arriaza et al. 2004 and GarcíaLlorente et al. 2012 for similar methodological approaches) of the two landscapes that are most characteristic of the study area: the pine forests of the Serranía de Cuenca and the croplands of La Mancha (Fig. 1). Two pairs of photographs, one of each landscape, were presented. The photographs were taken in May 
2010, in the same area and at the same moment, controlled for orientation, elevation, perspective, sky proportion, and other visual characteristics to display the same real landscape view, except for the presence of a drove road in one of the photographs (Fig. 1, pictures B and D) and the absence of a drove road in the other photograph (Fig. 1, pictures A and C). Adequacy and significance of the pictures with respect to the study objectives were evaluated by a group of researchers experienced in the use of photographs for social sciences studies and familiar with transhumance and the landscapes of the study area.

All respondents were provided with a brief explanation of the ecosystem services concept to ensure that they understood that it represents "the benefits that ecosystems provide for human wellbeing" (Millennium Ecosystem Assessment 2005:27, box 1.1). The connection of the survey with the study of transhumance was not revealed to respondents during the interview, and no assumption was made regarding the degree of people's perception or capacity to distinguish the drove road as a landscape feature before the application of the questionnaire. The respondents were asked to assess the degree of ecosystem services delivery on a scale ranging from 1 (nothing) to 4 (much/plenty), according to the following question: "To what extent do you perceive that the landscape in the photograph is delivering each of the listed ecosystem services?" Two questionnaire models, each with a list of ecosystem services in different orders, were used to avoid position bias (Bateman et al. 2002). A total of 16 ecosystem services (Appendix 2) were selected based on the most meaningful ecosystem services to people in these landscapes, as identified by previous research (Oteros-Rozas et al. 2012b). Five services were classified as provisioning services (feed for animals, gathering of wild products, food from agriculture, wood and timber, and livestock), five as cultural services (aesthetic value, cultural identity, tourism, hunting, and tranquility/relaxation), and six as regulating services (air purification, plant regeneration, fire prevention, soil erosion control, habitat for species, and connectivity).

The questionnaire also included a set of questions about certain socio-demographic characteristics, e.g., age, gender, the place of residence of respondents (see Appendix 1), and environmental awareness/attitudes, e.g., readers of environmental magazines, members of environmental associations, personal feelings about rural life. At the end of the interviews, the respondents were asked which of the two images in each pair they liked the best. This information was recorded as a proxy for drove road preference.

\section{Data analysis}

The comparison of perceptions about ecosystem services in cropland and pine forest landscapes (objective 1) was done using just the data set obtained from the photographs that did not contain drove roads. To compare ecosystem service perceptions in landscapes with and without a drove road (objective 2), we separately analyzed the data from each landscape pair. Descriptive statistics (mean frequencies and standard deviations) and Wilcoxon rank-sum tests were performed to identify and describe differences in ecosystem service perceptions between the cropland and the pine forest landscapes (objective 1) and between the landscapes with and without a drove road (objective 2).
The third objective was to explore how underlying socio-cultural variables may influence the perception of ecosystem services and the emergence of relationships between ecosystem services on the basis of visual stimuli. To accomplish this objective, we applied a redundancy analysis (RDA) for each landscape (cropland and pine forest). RDA (Rao 1964) is a tool commonly used for modeling dependent variables with their hypothetical predictors (Legendre and Legendre 1998). This statistical technique provides the means for conducting direct explanatory analysis, in which the association among ecosystem services may be explored with respect to their relationships with any set of predictors of interest. For instance, several recent studies have used this technique to model ecosystem service values through cultural and sociodemographic predictors (Hicks et al. 2009, Martín-López et al. 2012). We performed Monte Carlo permutation tests (1000 permutations) to determine the degree to which independent variables influenced people's perception of ecosystem services. The most important variables in terms of socio-cultural perception were identified based on their factor scores.

\section{RESULTS}

\section{Visual perception of ecosystem services in cropland and forest cultural landscapes}

For both the cropland and forest landscapes, respondents gave the highest scores to air purification, aesthetic value, and tranquility/relaxation. In comparison, the lowest respondent scores were obtained for feed for animals, gathering of wild products such as mushrooms, livestock, and connectivity. However, the mean scores for all perceived ecosystem services were significantly different between the cropland and forest ecosystems (Wilcoxon tests; $\mathrm{P}<0.001$ ), except for cultural identity (Fig. 2). According to the main categories of ecosystem services, provisioning services were mostly associated with the cropland landscape ( $9 \%$ more than forest), whereas regulating and cultural services were more closely linked to the forest landscape ( $12 \%$ and $15 \%$ more, respectively, than cropland). Hence, the cropland landscape was scored as providing a greater supply of feed for animals, agriculture, livestock, fire prevention, and connectivity. In comparison, forest landscapes were scored significantly higher for all other services. The strongest differences in perceived delivery between the two landscapes were for food from agriculture, which was associated with the cropland landscape, and wood and timber, which were clearly associated with the forest landscape.

All three types of ecosystem services were more strongly and significantly perceived by respondents for both the cropland and forest landscapes when a drove road was present in the picture (all Wilcoxon tests $\mathrm{P}<0.001$; Table 1). In particular, provisioning services were scored higher by $11 \%$ and $6 \%$ for forest and cropland landscapes, respectively, when a drove road was present. Perceived regulating services were scored higher by $5 \%$ and $13 \%$ for the forest and cropland landscapes, respectively, when a drove road was present. Cultural services also were scored higher by $7 \%$ and $10 \%$ for the forest and cropland landscapes, respectively, when a drove road was present. 
Table 1. Comparison of the perceptions about ecosystem services in the two study landscapes (croplands and pine forests), with and without the drove road, using the paired Wilcoxon signed-rank test. Mean scores (and standard deviation) are also shown. Significant at $* \mathrm{p} \leq 0.1, * * \mathrm{p} \leq 0.05, * * * \mathrm{p} \leq 0.01$.

\begin{tabular}{|c|c|c|c|c|c|c|c|c|c|c|}
\hline \multirow[t]{3}{*}{ Ecosystem Services } & \multicolumn{5}{|c|}{ Cropland } & \multicolumn{5}{|c|}{ Pine Forest } \\
\hline & \multicolumn{2}{|c|}{ No drove road } & \multicolumn{2}{|c|}{ Drove road } & \multirow[b]{2}{*}{$V$} & \multicolumn{2}{|c|}{ No drove road } & \multicolumn{2}{|c|}{ Drove road } & \multirow[b]{2}{*}{$V$} \\
\hline & Mean & S.D. & Mean & S.D. & & Mean & S.D. & Mean & S.D. & \\
\hline Provisioning & 2.40 & 0.55 & 2.55 & 0.57 & $9695.5 * * *$ & 2.19 & 0.52 & 2.43 & 0.52 & $23878.0 * * *$ \\
\hline Feed for animals & 2.36 & 0.95 & 3.00 & 0.83 & $2945.5 * * *$ & 1.88 & 0.93 & 2.64 & 0.95 & $19561.0 * * *$ \\
\hline Gathering & 2.23 & 1.06 & 2.33 & 0.93 & $5862.0 * *$ & 2.44 & 1.07 & 2.47 & 0.96 & 3775.5 \\
\hline Food from agriculture & 3.43 & 0.73 & 2.55 & 0.95 & $22452.0 * * *$ & 1.26 & 0.62 & 1.47 & 0.78 & $1850.0 * * *$ \\
\hline Wood and timber & 1.81 & 0.81 & 2.00 & 0.91 & $1428.5^{* * *}$ & 3.56 & 0.68 & 3.01 & 0.86 & $655.0 * * *$ \\
\hline Livestock & 2.15 & 0.91 & 2.85 & 0.93 & $1477.0 * * *$ & 1.82 & 0.95 & 2.57 & 0.98 & $17488.0 * * *$ \\
\hline Regulating & 2.46 & 0.52 & 2.78 & 0.52 & $3786.0 * * *$ & 2.75 & 0.49 & 2.95 & 0.49 & $26611.0 * * *$ \\
\hline Air purification & 3.33 & 0.80 & 3.44 & 0.67 & $735.0 * * *$ & 3.70 & 0.60 & 3.55 & 0.71 & $556.5 * * *$ \\
\hline Plant regeneration & 2.45 & 0.90 & 2.77 & 0.90 & $1872.0 * * *$ & 3.15 & 0.88 & 3.10 & 0.75 & 4845.5 \\
\hline Fire prevention & 2.43 & 0.98 & 2.43 & 0.94 & 5130.0 & 1.70 & 1.01 & 2.49 & 1.01 & $19525.5^{* * *}$ \\
\hline Soil erosion control & 2.18 & 0.88 & 2.45 & 0.92 & $2109.0 * * *$ & 3.01 & 1.01 & 2.69 & 0.90 & $3162.5 * * *$ \\
\hline Habitat for species & 2.32 & 0.85 & 2.70 & 0.85 & $1953.0 * * *$ & 3.03 & 0.89 & 2.97 & 0.81 & 3896.0 \\
\hline Connectivity & 2.04 & 0.89 & 2.89 & 0.83 & $1494.0 * * *$ & 1.89 & 0.97 & 2.91 & 0.81 & $25336.5^{* * *}$ \\
\hline Cultural & 2.51 & 0.52 & 2.75 & 0.56 & $7519.0 * * *$ & 2.89 & 0.62 & 3.02 & 0.56 & $18616.0 * * *$ \\
\hline Aesthetic values & 2.72 & 0.84 & 2.88 & 0.79 & $7309.0^{*}$ & 2.96 & 0.96 & 3.24 & 0.80 & $14745.0 * * *$ \\
\hline Cultural identity & 2.64 & 0.98 & 2.66 & 0.95 & 6438.5 & 2.52 & 0.95 & 2.78 & 0.90 & $9599.5 * * *$ \\
\hline Tourism & 1.77 & 0.85 & 2.19 & 0.99 & $1010.0 * * *$ & 2.43 & 1.02 & 2.77 & 0.95 & $8584.0 * * *$ \\
\hline Hunting & 2.31 & 0.92 & 2.68 & 0.89 & $1422.0 * * *$ & 2.97 & 0.88 & 2.92 & 0.83 & 3432.5 \\
\hline Tranquillity/relaxation & 3.13 & 0.90 & 3.35 & 0.76 & $1324.5 * * *$ & 3.54 & 0.72 & 3.38 & 0.83 & $1749.0 * * *$ \\
\hline
\end{tabular}

Fig. 2. Average scores (and standard deviation) of the perception about the capability of croplands and forests to deliver ecosystem services. Asterisks show significant differences between cropland and forest ecosystems using the Wilcoxon test $(\mathrm{p}<0.001)$.

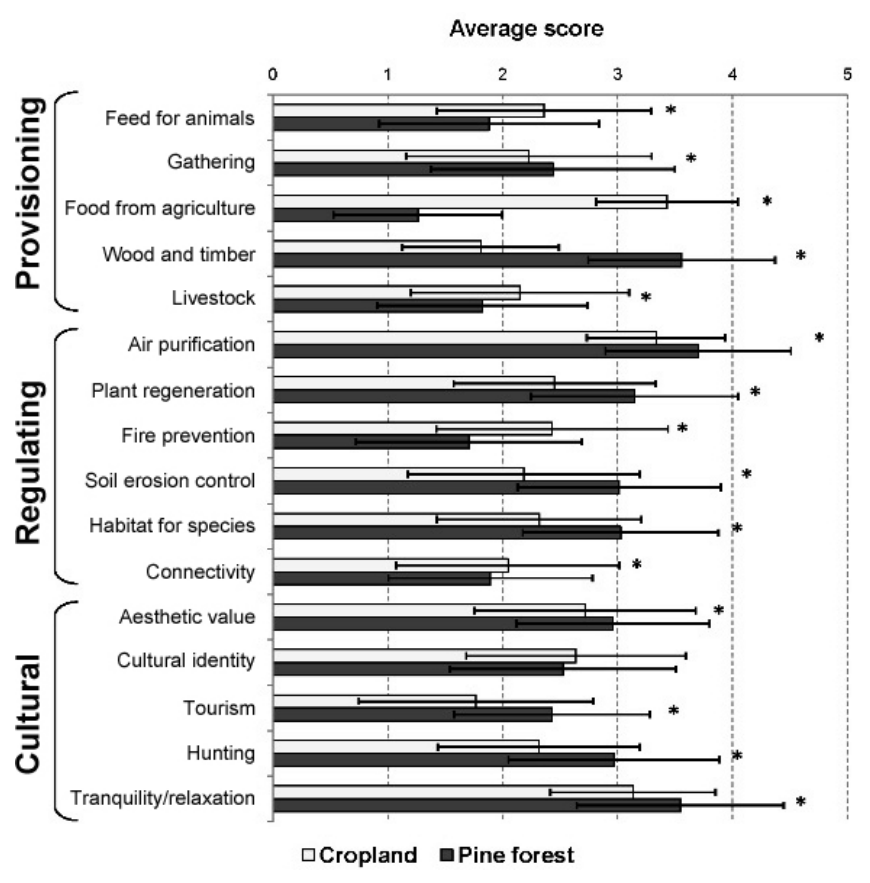

Effect of a transhumance drove road in visual perception of ecosystem services

The cropland landscape had higher scores for almost all single ecosystem services when the drove road was present, except for food from agriculture. Presence of the drove road did not make a statistically significant difference in perception of fire prevention and cultural identity (Table 1).

With the forest landscape, respondents were more likely to suggest that the forest with a drove road supplied the most ecosystem services (Table 1). However, we did not find any significant differences for four of the services: gathering of wild products, plant regeneration, habitat for species, and hunting. The provision of three other services, wood and timber, air purification, and soil erosion control, was considered greater in the forest without the drove road.

\section{Socio-cultural factors influencing appreciation of ecosystem services}

Multivariate analyses of RDAs indicated the presence of a significant association between the socio-cultural characteristics of respondents and how they perceived the supply of ecosystem services in both cropland and forest cultural landscapes (pseudo $F$ values of 0.229 and 0.239 , respectively; $\mathrm{P}<0.001$, from 1000 permutations in both cases). The first five axes of the RDAs explained $83.9 \%$ and $82.8 \%$ of the total variance in the La Mancha cropland and the pine forest landscapes, respectively. From this point forward, we primarily focused on the interpretation of axes 1 and 2 because they explained the most important trends related to ecosystem services perception, based on the explained variance and their eigenvalues (Tables 2 and 3).

In the case of the La Mancha cropland (Table 2, Fig. 3), preference for the presence of a drove road in the landscape was the main 
Table 2. Redundancy analysis results for the cropland landscape, showing the factor scores of ecosystem services and the variables related to the socioeconomic characteristics of the respondents. Eigenvalues, percentage of variance explained, cumulative percentage of variance explained, and inertia by axes (1-5) are also indicated. Bold values indicate the variables with the largest squared cosine in each of the axes. Note: D.R. = drove road.

\begin{tabular}{|c|c|c|c|c|c|c|c|c|c|c|}
\hline & \multicolumn{2}{|c|}{ AXIS 1} & \multicolumn{2}{|c|}{ AXIS 2} & \multicolumn{2}{|c|}{ AXIS 3} & \multicolumn{2}{|c|}{ AXIS 4} & \multicolumn{2}{|c|}{ AXIS 5} \\
\hline & No D.R. & D.R. & NOD.R. & D. R. & NOD.R. & D. R. & NO D.R. & D.R. & NO D.R. & D. R. \\
\hline \multicolumn{11}{|l|}{ Ecosystem Services } \\
\hline Feed for animals & 0.34 & 0.03 & 0.25 & 0.21 & -0.07 & -0.12 & -0.09 & -0.03 & 0.16 & -0.15 \\
\hline Gathering & 0.43 & 0.07 & -0.22 & 0.11 & 0.11 & -0.01 & -0.06 & 0.03 & 0.01 & -0.20 \\
\hline Food from agriculture & 0.00 & 0.01 & -0.01 & 0.40 & -0.24 & -0.01 & -0.07 & -0.36 & 0.12 & 0.28 \\
\hline Wood and timber & 0.56 & 0.55 & -0.13 & -0.07 & -0.09 & -0.08 & -0.05 & -0.06 & -0.09 & -0.14 \\
\hline Livestock & 0.25 & -0.18 & 0.25 & 0.42 & 0.06 & 0.02 & -0.01 & 0.01 & 0.14 & -0.03 \\
\hline Air purification & 0.44 & 0.30 & -0.18 & -0.03 & -0.01 & -0.05 & -0.04 & -0.03 & -0.08 & -0.13 \\
\hline Plant regeneration & 0.76 & 0.36 & 0.13 & 0.25 & -0.04 & -0.17 & 0.12 & 0.03 & 0.00 & -0.20 \\
\hline Fire prevention & -0.21 & -0.11 & 0.04 & 0.10 & -0.02 & -0.11 & 0.38 & 0.31 & 0.01 & 0.23 \\
\hline Soil erosion control & 0.30 & -0.02 & 0.23 & 0.19 & 0.01 & -0.18 & 0.27 & 0.34 & -0.02 & -0.04 \\
\hline Habitat for species & 0.39 & 0.01 & 0.07 & 0.11 & 0.10 & 0.00 & 0.11 & 0.09 & 0.05 & -0.05 \\
\hline Connectivity & 0.11 & -0.13 & 0.10 & 0.40 & 0.07 & -0.20 & 0.04 & -0.01 & 0.02 & 0.09 \\
\hline Aesthetic values & 0.58 & -0.03 & 0.18 & 0.38 & 0.08 & -0.09 & 0.15 & -0.11 & 0.28 & -0.10 \\
\hline Cultural identity & 0.30 & -0.18 & -0.09 & 0.35 & 0.47 & 0.21 & 0.12 & 0.02 & 0.04 & -0.22 \\
\hline Tourism & 0.30 & -0.18 & 0.21 & 0.46 & 0.05 & -0.03 & -0.04 & -0.04 & 0.02 & -0.14 \\
\hline Hunting & -0.03 & -0.01 & 0.22 & 0.21 & 0.47 & 0.41 & -0.12 & 0.04 & 0.06 & -0.14 \\
\hline $\begin{array}{r}\text { Tranquillity/ } \\
\text { relaxation }\end{array}$ & 0.55 & 0.23 & -0.05 & 0.19 & -0.10 & -0.07 & -0.13 & -0.10 & -0.02 & -0.07 \\
\hline \multicolumn{11}{|l|}{ Respondents' } \\
\hline \multicolumn{11}{|l|}{ Characteristics } \\
\hline Studies Level & \multicolumn{2}{|l|}{-0.06} & \multicolumn{2}{|c|}{-0.20} & \multicolumn{2}{|c|}{-0.16} & \multicolumn{2}{|c|}{-0.11} & \multicolumn{2}{|c|}{0.02} \\
\hline Visit frecuency & \multicolumn{2}{|l|}{-0.25} & \multicolumn{2}{|c|}{0.14} & \multicolumn{2}{|c|}{0.16} & \multicolumn{2}{|c|}{-0.17} & \multicolumn{2}{|c|}{-0.02} \\
\hline Environmental reader & \multicolumn{2}{|l|}{-0.32} & \multicolumn{2}{|c|}{-0.02} & \multicolumn{2}{|c|}{0.05} & \multicolumn{2}{|c|}{-0.08} & & \\
\hline Age & -0.13 & & & & & & & & & \\
\hline Serranía residents & -0.06 & & & & & & & & & \\
\hline La Mancha residents & 0.17 & & & & & & & & & \\
\hline Rural & -0.12 & & & & & & & & & \\
\hline Semirural & 0.11 & & & & & & & & & \\
\hline Urban & 0.03 & & & & & & & & & \\
\hline Rural sense & -0.13 & & & & & & & & & \\
\hline $\begin{array}{l}\text { Experience with } \\
\text { transhumance }\end{array}$ & -0.29 & & & & & & & & & \\
\hline Gender-male & -0.28 & & & & & & & & & \\
\hline Gender-female & 0.28 & & & & & & & & & \\
\hline $\begin{array}{r}\text { Environmental } \\
\text { education }\end{array}$ & -0.32 & & & & & & & & & \\
\hline Herders & -0.21 & & & & & & & & & \\
\hline Farmers & 0.09 & & & & & & & & & \\
\hline $\begin{array}{r}\text { No Drove Road } \\
\text { Preference }\end{array}$ & 0.34 & & & & & & & & & \\
\hline $\begin{array}{r}\text { Drove Road } \\
\text { Preference }\end{array}$ & -0.34 & & & & & & & & & \\
\hline RDA Statistics & & & & & & & & & & \\
\hline Eigenvalue & 0.93 & & & & & & & & & \\
\hline Variance exp (\%) & 37.91 & & & & & & & & & \\
\hline Cumulative \% & 37.91 & & & & & & & & & \\
\hline Total inertia & 3.68 & & & & & & & & & \\
\hline
\end{tabular}

explanatory variable on the first axis, explaining $37.9 \%$ of the total variance. Local residents from La Mancha, inhabitants of semirural cities (see Appendix 1 for the definition of semirural) and big cities, and female respondents gave higher scores for aesthetic value, tranquility/relaxation, air purification, gathering of wild products, wood/timber, habitat for species, and plant regeneration to the landscape without the drove road. In contrast, people with environmental sciences education, readers of environmental magazines, herders, older people, and those who had previous experience with transhumance showed a clear preference for the landscape with a drove road, with greater appreciation for the importance of livestock, connectivity, 
Table 3. Redundancy analysis results for the pine forest landscape, showing the factor scores of ecosystem services and the variables related to the socioeconomic characteristics of the respondents. Eigenvalues, percentage of variance explained, cumulative percentage of variance explained, and inertia by axes (1-5) are also indicated. Bold values indicate the variables with the largest squared cosine in each of the axes.

\begin{tabular}{|c|c|c|c|c|c|c|c|c|c|c|}
\hline & \multicolumn{2}{|c|}{ AXIS 1} & \multicolumn{2}{|c|}{ AXIS 2} & \multicolumn{2}{|c|}{ AXIS 3} & \multicolumn{2}{|c|}{ AXIS 4} & \multicolumn{2}{|c|}{ AXIS 5} \\
\hline & NOD.R. & D. R. & NO D.R. & D.R. & NO D.R. & D. R. & NO D.R. & D.R. & NO D.R. & D. $R$. \\
\hline \multicolumn{11}{|l|}{ Ecosystem Services } \\
\hline Feed for animals & -0.04 & -0.23 & -0.09 & -0.41 & 0.38 & 0.21 & 0.00 & -0.05 & 0.21 & 0.17 \\
\hline Gathering & 0.19 & -0.12 & -0.51 & -0.49 & -0.10 & -0.03 & -0.02 & -0.07 & 0.19 & 0.11 \\
\hline Food from agriculture & 0.04 & -0.09 & 0.07 & 0.14 & 0.19 & 0.25 & 0.02 & 0.02 & 0.08 & -0.06 \\
\hline Wood and timber & 0.35 & 0.51 & 0.00 & -0.04 & 0.07 & 0.15 & -0.13 & -0.43 & 0.04 & 0.03 \\
\hline Livestock & -0.17 & -0.37 & -0.25 & -0.44 & 0.13 & 0.05 & 0.24 & 0.24 & 0.17 & -0.14 \\
\hline Air purification & 0.30 & 0.30 & -0.04 & -0.04 & -0.04 & 0.10 & -0.04 & -0.16 & 0.11 & -0.04 \\
\hline Plant regeneration & 0.43 & 0.12 & -0.07 & -0.12 & 0.09 & 0.08 & -0.03 & -0.13 & 0.01 & 0.02 \\
\hline Fire prevention & -0.24 & -0.29 & 0.13 & -0.33 & 0.54 & 0.21 & 0.11 & 0.14 & 0.00 & -0.04 \\
\hline Soil erosion control & 0.08 & -0.06 & -0.34 & -0.31 & -0.36 & -0.10 & 0.16 & 0.00 & 0.15 & 0.17 \\
\hline Habitat for species & 0.41 & 0.13 & -0.18 & -0.28 & -0.01 & -0.04 & 0.02 & -0.20 & -0.04 & -0.02 \\
\hline Connectivity & 0.05 & -0.23 & -0.19 & -0.38 & -0.16 & -0.01 & 0.20 & -0.19 & -0.20 & -0.12 \\
\hline Aesthetic values & 0.75 & -0.01 & 0.10 & -0.16 & 0.12 & 0.18 & 0.42 & -0.27 & -0.06 & -0.24 \\
\hline Cultural identity & 0.34 & -0.17 & -0.23 & -0.38 & 0.25 & 0.16 & 0.29 & -0.12 & -0.03 & -0.11 \\
\hline Tourism & 0.44 & -0.01 & -0.34 & -0.48 & 0.03 & -0.04 & 0.23 & -0.09 & -0.12 & -0.24 \\
\hline Hunting & 0.18 & 0.13 & -0.16 & -0.25 & 0.19 & -0.13 & -0.04 & 0.02 & 0.01 & 0.04 \\
\hline Tranquility/relaxation & 0.27 & 0.29 & -0.04 & -0.09 & 0.01 & 0.04 & 0.06 & -0.25 & -0.04 & 0.04 \\
\hline
\end{tabular}

Respondents'

Characteristics

\begin{tabular}{|c|c|c|c|c|c|}
\hline & & & & & \\
\hline Studies Level & 0.31 & -0.08 & -0.20 & -0.19 & 0.02 \\
\hline Visit frequency & -0.10 & -0.17 & 0.09 & 0.02 & -0.06 \\
\hline Environmental reader & -0.03 & -0.15 & -0.16 & 0.05 & -0.09 \\
\hline Age & -0.31 & -0.08 & -0.07 & 0.25 & 0.00 \\
\hline Serranía residents & -0.09 & -0.11 & 0.19 & -0.11 & -0.10 \\
\hline La Mancha residents & -0.03 & 0.07 & -0.01 & 0.05 & 0.12 \\
\hline Rural & -0.26 & -0.12 & 0.10 & -0.07 & 0.14 \\
\hline Semirural & 0.09 & 0.13 & -0.04 & 0.02 & -0.14 \\
\hline Urban & 0.18 & 0.02 & -0.06 & 0.05 & -0.03 \\
\hline Rural sense & -0.14 & -0.01 & -0.04 & -0.09 & -0.07 \\
\hline Experience with transhumance & -0.11 & -0.17 & -0.07 & -0.06 & -0.09 \\
\hline Gender-male & -0.20 & 0.08 & -0.15 & 0.09 & -0.08 \\
\hline Gender-female & 0.20 & -0.08 & 0.15 & -0.09 & 0.08 \\
\hline Environmental education & 0.11 & -0.26 & -0.16 & 0.02 & -0.08 \\
\hline Herders & -0.26 & -0.11 & 0.15 & -0.11 & -0.12 \\
\hline Farmers & -0.04 & 0.13 & -0.11 & 0.06 & 0.12 \\
\hline No Drove Road Preference & 0.33 & 0.02 & 0.00 & 0.29 & 0.04 \\
\hline Drove Road Preference & -0.33 & -0.02 & 0.00 & -0.29 & -0.04 \\
\hline DA Statistics & & & & & \\
\hline Eigenvalue & 0.71 & 0.64 & 0.30 & 0.29 & 0.13 \\
\hline Variance exp $(\%)$ & 28.59 & 25.66 & 11.95 & 11.54 & 5.14 \\
\hline Cumulative $\%$ & 28.59 & 54.25 & 66.20 & 77.74 & 82.88 \\
\hline Total inertia & 2.88 & 2.58 & 1.20 & 1.16 & 0.52 \\
\hline
\end{tabular}

cultural identity, and tourism in this picture. The second axis revealed a marked dichotomy between rural and urban respondents that explained $19.5 \%$ of the total variance. One side of the axis was associated with rural inhabitants, residents of the pine forest area, herders, older people, and those with transhumance experience. These respondents tended to give higher scores for food from agriculture, livestock, connectivity, tourism, aesthetic value, and cultural identity to the landscape with the drove road. The other side of the axis was associated with urban people, who showed a greater appreciation for air purification, gathering of wild products, and relaxation, especially when the drove road was absent.
Similarly, in the case of the pine forest (Table 3, Fig. 4), the first axis revealed a dichotomy in terms of preferences for the landscapes with and without a drove road that explained $28.6 \%$ of the total variance. This dichotomy was associated with differences in rural-urban perceptions. Youngsters, people with higher levels of education, women, and urban inhabitants preferred landscapes without a drove road and had a stronger appreciation of aesthetic value, tourism, tranquility/relaxation, air purification, plant regeneration, and habitat for species, as well as wood and timber. In contrast, the negative loadings of this axis were associated with herders and other rural people, who expressed a clear preference for drove roads, providing higher 
Fig. 3. Biplot resulting from RDA (redundancy analysis) factors 1 (37.9\% of variance explained) and 2 (19.5\% of variance) for ecosystem services public appreciation in the pair of photographs depicting the La Mancha cropland. Ecosystems services suggested for landscape picture with a drove road (Fig. 1D) are presented in blue, while the ecosystems services suggested for the landscape picture without a drove road (Fig. 1C) are presented in green. The ovals indicate the four groups of respondents identified.

RDA Biplot (axes F1 and F2: $57.4 \%$ )

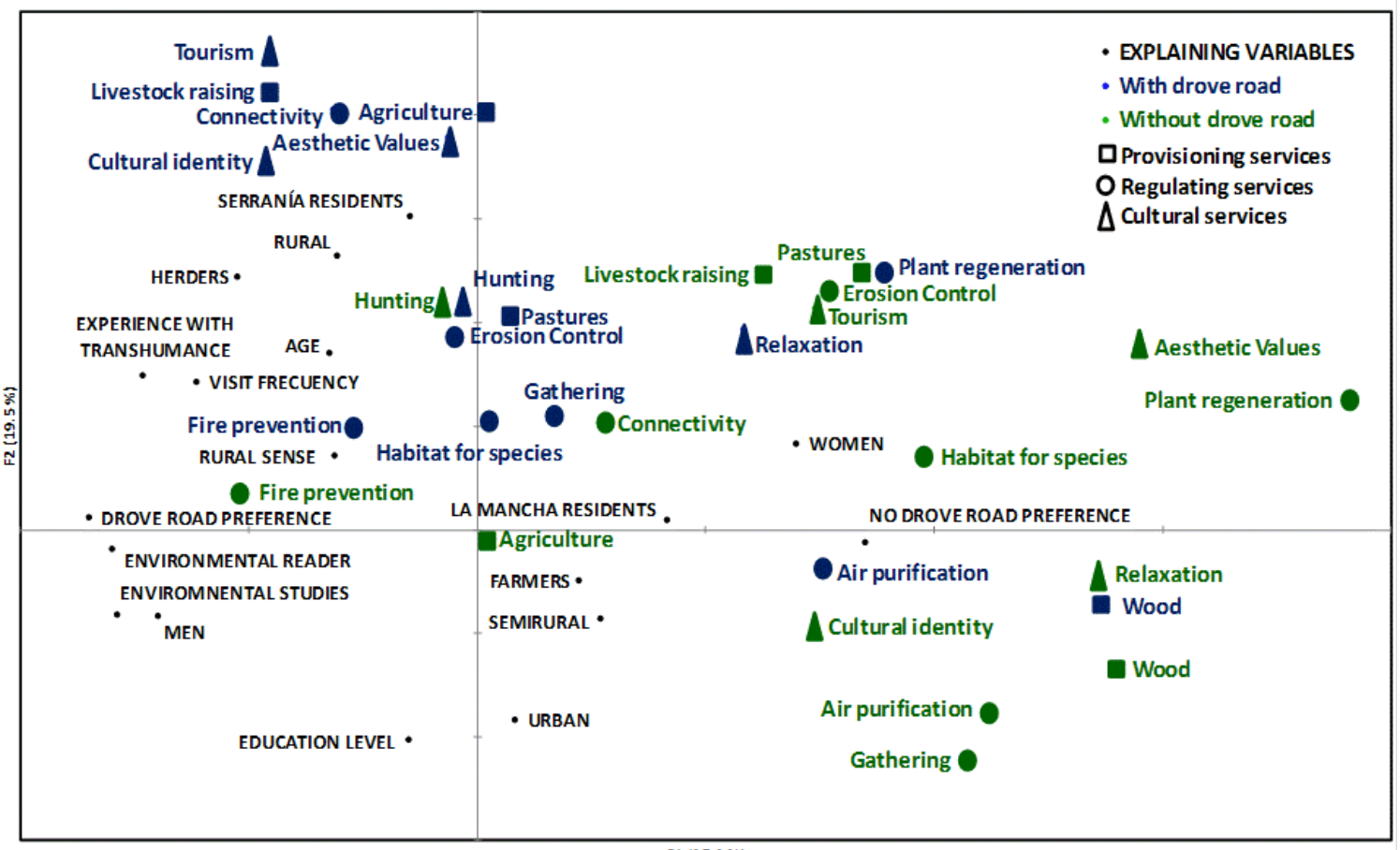

scores for livestock, fire prevention, connectivity, and cultural identity when a drove road was present. People with a background in environmental studies, farmers, and La Mancha residents had very low loadings for this factor. The second axis, explaining $25.7 \%$ of the total variance, reflected the perceptions of farmers from the cropland area of La Mancha and semirural people, who gave high scores for agriculture to both images and for fire prevention to the image without a drove road. In contrast, environmentalists, those who frequently visit the zone, readers of environmental magazines, and those with transhumance experience were more likely to perceive gathering of wild products as a service provided by pine forests, either with or without the drove road. They also showed a high appreciation for livestock, pastures, soil erosion control, fire prevention, habitat for species, connectivity, tourism, and cultural identity, primarily giving higher scores to the image with the drove road.

\section{DISCUSSION}

\section{Forests versus cropland landscapes as providers of ecosystem} services

This study demonstrated that people generally perceive forests as providing a wider range of ecosystem services than croplands. This better societal visibility of forests as ecosystem service providers accords with the findings of previous research
(Harrison et al. 2010, Montes et al. 2011, Martín-López et al 2012). The cropland landscapes of La Mancha were perceived as supplying more provisioning services such as the production of food and feed, while potentially jeopardizing the provision of regulating and cultural services. This observation confirms a welldocumented trade-off between provisioning services and regulating/cultural services in agroecosystems (Gordon et al. 2010). In contrast, forests were perceived as better suppliers of regulating and cultural services such as hunting, tourism, tranquility, and aesthetic value, while simultaneously producing wood and timber. The high perception of the aesthetic value of forests could be interpreted as an expression of phytophilia (Ulrich 1986, Ulrich 1990, López-Santiago 1994), which is the phenomenon of people generally preferring green, lush, forested vistas over arid landscapes (DeLucio and Múgica 1994).

Several previous studies reported greater social perception of provisioning services compared with regulating and cultural services (Iftekhar and Takama 2008, Agbenyega et al. 2009, Hartter 2010). In contrast, our results indicate that both cultural and regulating services were strongly perceived in both landscapes, even more than provisioning services. Similar results were obtained by other studies that used visual stimuli and verbal methods in Mediterranean landscapes (Castro et al. 2011, GarcíaLlorente et al. 2012, Palomo et al. 2013). In general there is a high 
Fig. 4. Biplot resulting from RDA (redundancy analysis) factors 1 (28.6\% of variance explained) and 2 (25.7\% of variance) for ecosystem services public appreciation in the pair of photographs depicting the Serranía de Cuenca pine forest. Ecosystems services suggested for the landscape picture with a drove road (Fig. 1B) are presented in blue, while the ecosystems services suggested for the landscape picture without a drove road (Fig. 1A) are presented in green. The ovals indicate the four groups of respondents identified.

RDA Biplot (axes F1 and F2: $54.25 \%$ )

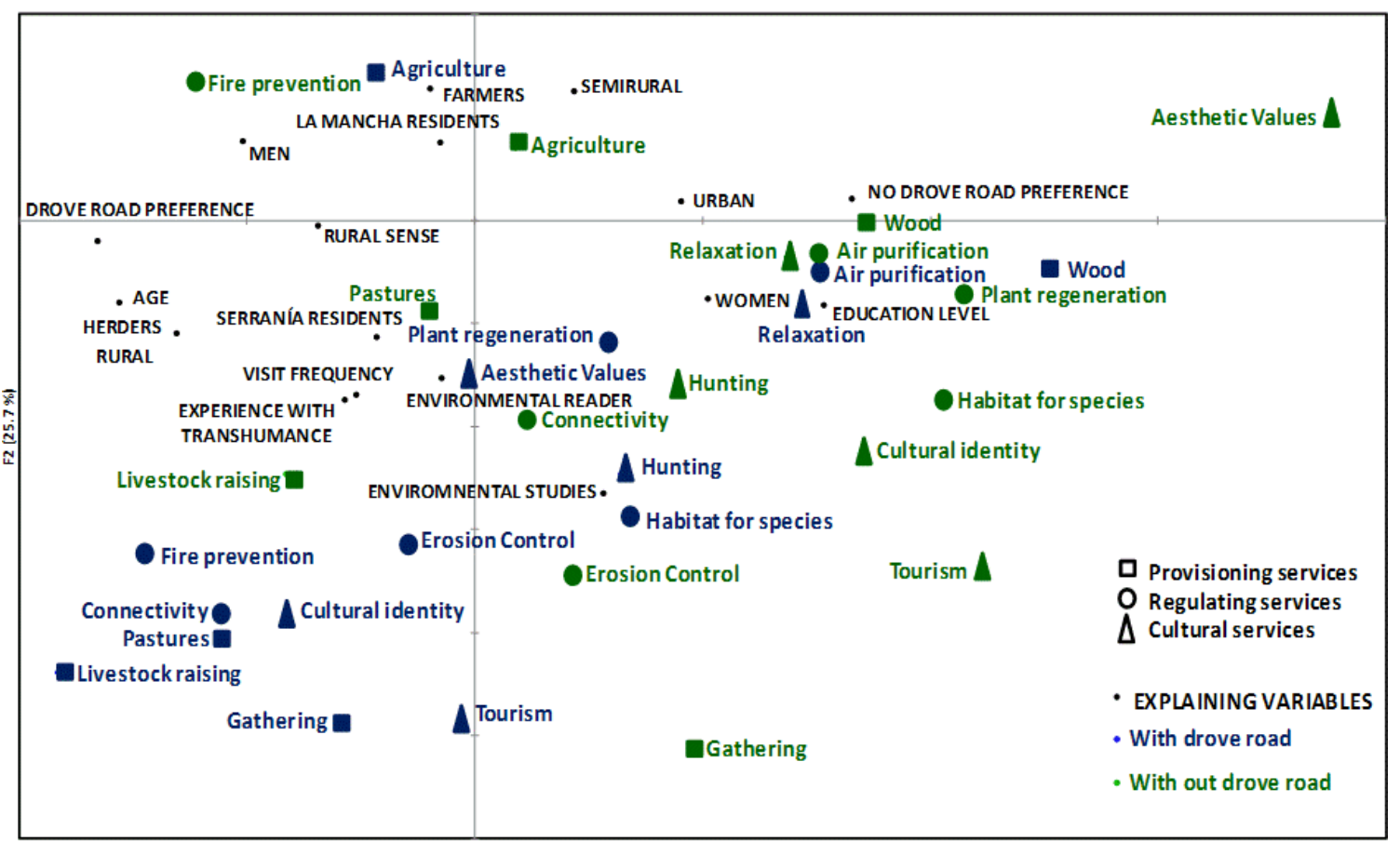

perception of cultural and regulating services in cultural landscapes. This bias probably arises because multifunctional landscapes are socially associated with cultural values and traditional practices, in parallel to the traditional management of these landscapes being historically associated with the management of particular regulating services such as soil formation or water regulation (Martín-López et al. 2012).

\section{The drove road as a diversifying landscape feature}

Landscapes with a drove road were perceived by respondents as being providers of more ecosystem services than landscapes without a drove road. This perception was particularly strong with respect to feed for animals, livestock, and connectivity in both landscape types, and fire prevention in forests (Table 1). These results are consistent with those of previous studies on the socio-cultural valuation of transhumance-related ecosystem services (Oteros-Rozas et al. 2013) and the demonstrated ecological role of drove roads for biological connectivity (Bunce et al. 2006, Manzano and Malo 2006). However, to our knowledge, our study is the first to report that the importance of drove roads is effectively recognized by a diverse sample of the population, both locals and visitors, and that the drove road is a distinct visual landscape element responsible for the delivery of a diverse number of ecosystem services. In the context of Mediterranean landscapes, the drove road is generally perceived as evidence of landscape multifunctionality and thus is important for the delivery of ecosystem services.

\section{Public attitudes toward transhumance drove roads in cultural landscapes}

Previous research has shown that different user groups differ in their appreciation of landscape development plans, depending on their background (Van den Berg et al. 1998) and particularly their environmental value orientations (Kaltenborn and Bjerke 2002). The literature on sense of place has also demonstrated how the multiple physical and social bonds and attitudes of people toward the environment are connected with the visual aspects and use values perceived in landscape (Jorgensen and Steadman 2001, Soini et al. 2012). The perception of ecosystem services has also been demonstrated to differ according to socio-demographic factors and individual backgrounds (Lamarque et al. 2011, Martín-López et al. 2012, Plieninger et al. 2013). We found that social appreciation of the supply of ecosystem services in cultural landscapes was clearly associated with certain characteristics of the respondents: their rootedness and identification with the place, environmental knowledge, recreational needs, and economic dependence on the place. Social appreciation of ecosystem services was also strongly connected with personal preferences about the presence of a drove road. We identified four stakeholder groups that differed in their appreciation of 
ecosystem services, transhumance landscape preferences, and socio-demographic characteristics: people rooted in transhumance (group A), people who were environmentally aware (group B), urban inhabitants with recreational needs (group C), and farmers with strong cultural identity (group D; Figs. 3 and 4).

\section{Group A: people rooted in transhumance}

Herders and local residents of small villages in the summering area, most of whom were linked in some way to pastoralism and transhumance, constituted this aged and predominantly male group, as is usual in Spanish rural areas subjected to processes of aging, depopulation, and masculinization (Camarero and Sampedro 2008, Ministerio de Agricultura, Alimentación y Medio Ambiente 2010, Ministerio de Medio Ambiente y Medio Rural y Marino 2011) during recent decades. People in this group were particularly attracted to both landscapes with drove roads and tended to perceive the importance of pastures, livestock, fire prevention, connectivity, aesthetic value, cultural identity, and tourism. These perceptions were probably connected with the historical links of the population in the summering area with transhumance, as has been observed for decades in other mountain areas of Mediterranean Spain (Ruiz and GonzálezBernáldez 1983).

\section{Group B: people who were environmentally aware}

This group comprised highly environmentally friendly people, urban dwellers, and those with some existing knowledge of transhumance. They were mostly attracted to the presence of a drove road and had perceptions similar to those of group A regarding the cropland landscape; however, they preferred the picture with the drove road in the forest landscape to a lesser degree. This group's awareness about the forest differed from that of group $\mathrm{A}$ in that they recognized less cultural identity and aesthetic value in the picture with the drove road. Group B appreciated the pine forest for its greater provision of biodiversity, hunting, gathering of wild products, and erosion control. In addition, connectivity was appreciated when the drove road was not present, as if this group believed that connectivity was more related to forest wildlife than to livestock. Widely described patterns of biophilia (the urge to affiliate with other forms of life; Ulrich 1995) might explain this result. Significant and positive correlations have been previously found between environmentalism and a preference for the wilderness (Kaltenborn and Bjerke 2002) as an unpredictable, uncontrolled, and challenging landscape (López-Santiago 1994).

\section{Group C: urban inhabitants with recreational needs}

This group included people belonging to the urban environment, inhabitants of small cities, and those who did not feel particularly rural. This group had medium-high educational levels, but their education was not focused on environmental topics. The group was mostly composed of women who preferred the landscape without a drove road. Respondents belonging to this group appreciated tranquility/relaxation, wood, air purification, and plant regeneration in all tested images. They perceived more ecosystem services being supplied by the landscape picture without a drove road. This group did not seem to be aware of transhumance and did not pay attention to the presence of a drove road in the landscape. They had a noticeable affinity to ecosystem services that people living in stressful and polluted environments demand, including air purification, relaxation, and aesthetic value
(Martín-López et al. 2012). Previous studies reported that landscape preference might be influenced by the environment experienced on a daily basis, i.e., urban versus rural, and educational level ( $\mathrm{Yu}$ 1995). Basically, city-oriented people usually reject predictable, controlled, and human-influenced landscapes (López-Santiago 1994).

\section{Group D: farmers with strong cultural identity}

Farmers, elderly people, respondents living in small cities or rural areas, and those holding a strong rural feeling perceived markedly cultural identity and hunting in both images of their local agrarian landscape. This group did not have a specific preference for the drove road picture and tended to perceive higher connectivity and aesthetic value when it was absent. Furthermore, these farmers perceived gathering, fire prevention, and soil erosion control as ecosystem services that were provided by their most familiar landscape, which was probably related to their local ecological knowledge of the La Mancha agroecosystem. In the forest without the drove road, they perceived aesthetics, food from agriculture, and fire prevention more frequently than other stakeholder groups. Farmers have frequently been recognized as a very distinctive group (Lamarque et al. 2011), with a relatively high appreciation of farmland and humanized landscapes (e.g., see Van der Berg et al. 1998, Swift et al. 2004). This group is analogous to the farmers described in the past by GonzálezBernáldez and Parra (1979), who were observed to prefer predictable, controlled, and human-influenced landscapes, for which a drove road would probably be perceived as a disturbance in a cropland-oriented landscape.

\section{Usefulness of visual enquiries as a means of public participation in decision-making processes}

Compatibility among the demands of the four citizen groups characterized here, with their different values and world views, is a complex issue. The urbanization of society has increasingly led to land use changes that triggered the major development of settlements, changed the role of traditional provisioning services, and created new aspirations for recreation and leisure uses. This process influences the delivery of ecosystem services in many ways (Millennium Ecosystem Assessment 2005, Metzger et al. 2006, Ericksen 2008), leading to conflicts among different landscape management options (Foley et al. 2005) that require identification to appropriately inform policy decision making.

This study uncovered a type of decoupling between certain citizen groups and cultural landscape multifunctionality, resulting in trade-offs between urban/semirural people with a bucolic view of nature who pursue recreation services and more productionoriented farmers who demand ecosystem services such as food from agriculture (Figs. 3 and 4). Furthermore, these views clearly differ from the traditional view of transhumant herders and local residents of transhumance rural areas connected with multifunctional landscapes that deliver a broad range of ecosystem services. The environmentally aware group seemed to be the closest to this last-mentioned group; however, the environmentally aware group also included demands for some urban amenities such as tourism and recreation services. To fulfill either demand, one would have to adopt different land management models at different policy levels.

It is essential to take public opinion into account and involve all stakeholders in decision-making processes to ensure public 
support of maintaining cultural landscapes. Preliminary ecosystem services research has focused on monetary and biophysical valuations, with few studies specifically exploring socio-cultural preferences (Vihervaara et al. 2010). Our methodology has yielded some satisfactory results in revealing the perceptions of different people about ecosystem services in cultural landscapes. The use of visual stimuli in particular has proven, in our view, to be a useful technique for elucidating socialecological perceptions, using the landscape as a friendly communication channel and the ecosystem services framework as a code easily understood by stakeholders. Using this approach to score people's perceptions, we could potentially compare ecosystem services regardless of their level of incommensurability, and beyond their market value.

Research studies support the belief that people's perception and experience of landscape surroundings are key factors for understanding social interactions with the environment (Kaplan 1987, Appleton 1996, Daniel 2001, Gobster et al. 2007). Ultimately, evaluations based on visual stimuli are directly linked with human evolutionary perception skills and with innate human behavior in the search for well-being.

This study demonstrated how photographs might easily be used to facilitate the understanding of emotional, cultural, and spiritual bonds between different aspects of society such as lifestyles and ecosystems, as a complement to other in-depth qualitative methods. Models developed by environmental psychology (Daniel 2001) have shown that the human perceptual system is a tool designed through evolution, which is concerned with both survival and adaptation to ecosystems. Many studies have shown how through history our innate biophilic tendencies have been strongly modulated by cultural influences to fit into particular ecological contexts, while generating strong feelings of identity (Falk and Balling 2010). When people were asked about the ecosystem services that they perceived as being supplied by different landscapes, their answers tended to be strongly influenced by their origin, demands, and world views. Therefore, we believe that the presented methodological approach could potentially serve as a complementary approach to verbal enquiries, because visual assessments help to avoid misunderstandings that usually arise with verbal abstractions, which are not always adequately understood by everybody.

To our knowledge, this study represents the first attempt to explore ecosystem services through visual stimuli. Therefore, we acknowledge some limitations regarding our results and methodology. First, the sample error invites caution when interpreting the results. Second, further research is needed to validate the methodology under different circumstances and in other social-ecological systems. Other studies using the same or similar methods might also refine the proposed visual-stimuli approach for socio-cultural valuation of ecosystem services. We hope that this study and future work will help researchers assess the reliability of the visual perception method. Two potential limitations that should be taken into account in further applications of this approach are the great influence that the following two factors might have on the results: (1) sample selection, for which a deep previous knowledge about the relevant stakeholders involved in the social-ecological system is required, and (2) photograph selection, for which previous testing with potential interviewees and experts is needed.
In conclusion, we believe that this methodological approach could help to improve cultural landscapes planning by (1) making the wide range of ecosystem services delivered by cultural landscapes visible, (2) providing information about people's perceptions of the delivery of ecosystem services, (3) uncovering the sociocultural factors that determine social appreciation of and preferences for the delivery of ecosystem services, and (4) drawing attention to the consequences of changes in land use in terms of ecosystem services trade-offs.

Responses to this article can be read online at: http://www.ecologyandsociety.org/issues/responses. $\mathrm{php} / 6401$

\section{Acknowledgments:}

This research was financed by the Spanish Ministry for the Environment and Rural and Marine Affairs (Project 079/ RN08/02.1) and the Ministry of Economy and Competitiveness (Project CGL2011-30266). We are particularly grateful to $V$. Hevia, J. Cobo, B. Garzón, and R. Ontillera for their help with questionnaires. We also thank two anonymous referees for their useful comments on a previous version of the manuscript. Dr. Plieninger acknowledges support from the German Ministry of Education and Research (FKZ 01UU 0904) and the European Commission (Project HERCULES, grant agreement no. 603447, FP7-ENV-2013-two-stage).

\section{LITERATURE CITED}

Agbenyega, O., P. J. Burgess, M. Cook, and J. Morris. 2009. Application of an ecosystem function framework to perceptions of community woodlands. Land Use Policy 26(3):551-557. http:// dx.doi.org/10.1016/j.landusepol.2008.08.011

Appleton, J. 1996. The experience of landscape. Revised edition. Wiley, New York, New York, U.S.A.

Arriaza, M., J. F. Cañas-Ortega, J. A. Cañas-Madueño, and P. Ruiz-Aviles. 2004. Assessing the visual quality of rural landscapes. Landscape and Urban Planning 69(1):115-125. http://dx.doi. org/10.1016/i.landurbplan.2003.10.029

Bateman, I. J., R. T. Carson, B. Day, W. M. Hanemann, N. Hanley, T. Hett, M. Jones-Lee, G. Loomes, S. Mourato, E. Özdemiroglu, D. W. Pearce, R. Sugden, and J. Swanson. 2002. Economic valuation with stated preference techniques: a manual. Edward Elgar, Cheltenham, UK.

Beilin, R. 2005. Photo-elicitation and the agricultural landscape: 'seeing' and 'telling' about farming, community and place. Visual Studies 20(1):56-68. http://dx.doi.org/10.1080/14725860500064904

Berbés-Blázquez, M. 2012. A participatory assessment of ecosystem services and human wellbeing in rural Costa Rica using photo-voice. Environmental Management 49(4):862-875 http://dx. doi.org/10.1007/s00267-012-9822-9

Beymer-Farris, B., T. J. Bassett, and I. Bryceson. 2012. Promises and pitfalls of adaptive management in resilience thinking: the lens of political ecology. Pages 283-300 in T. Plieninger and C. Bieling, editors. Resilience and the cultural landscape: 
understanding and managing change in human-shaped environments. Cambridge University Press, Cambridge, UK. http://dx.doi.org/10.1017/CBO9781139107778.020

Blondel, J. 2006. The 'design' of Mediterranean landscapes: a millennial story of humans and ecological systems during the historic period. Human Ecology 34(5):713-729. http://dx.doi. org/10.1007/s10745-006-9030-4

Blondel, J., J. Aronson, J.-Y. Bodiou, and G. Boeuf. 2010 The Mediterranean region: biological diversity through space and time. Second edition. Oxford University Press, Oxford, UK.

Bunce, R. G. H., I. De Aranzabal, M. F. Schmitz, and F. D. Pineda. 2006. A review of the role of Drove Roads (Cañadas) as ecological corridors. Alterra-rapport 1428. ALTERRA, Wageningen, The Netherlands.

Bunce, R. G. H., M. Pérez-Soba, R. H. G. Jongman, A. Gómez Sal, F. Herzog, and I. Austad, editors. 2004. Transhumance and biodiversity in European mountains. Report of the EU-FP5 project TRASHUMOUNT (EVK-CT-2002-80017). IALE publication series nr 1. ALTERRA, Wageningen, The Netherlands.

Camarero, L., and R. Sampedro. 2008. Why are women leaving? The mobility continuum as an explanation of rural masculinization process. Revista Española de Investigaciones Sociologicas 124:73-105. http://dx.doi.org/10.2307/40184907

Carlsson, B. 2001. Depicting experiences. Scandinavian Journal of Educational Research 45(2):125-143 http://dx.doi. org/10.1080/00313830120052723

Castro A. J., B. Martín-López, M. García-Llorente, P. A. Aguilera, E. López, and J. Cabello. 2011. Social preferences regarding the delivery of ecosystem services in a semiarid Mediterranean region. Journal of Arid Environments 75 (11):1201-1208. http://dx.doi.org/10.1016/j.jaridenv.2011.05.013

Chan, K. M. A., L. Hoshizaki, and B. Klinkenberg. 2011. Ecosystem services in conservation planning: targeted benefits vs. co-benefits or costs? PLoS ONE 6(9):e24378. http://dx.doi. org/10.1371/journal.pone.0024378

Chan, K. M. A., T. Satterfield, and J. Goldstein. 2012. Rethinking ecosystem services to better address and navigate cultural values. Ecological Economics 74:8-18. $\quad$ http://dx.doi.org/10.1016/j. ecolecon.2011.11.011

Chan, K. M. A., M. R. Shaw, D. R. Cameron, E. C. Underwood, and G. C. Daily. 2006. Conservation planning for ecosystem services. PLoS Biology 4(11):e379. http://dx.doi.org/10.1371/ journal.pbio.0040379

Council of Europe. 2000. European Landscape Convention. European Treaty Series No. 176. Council of Europe, Florence, Italy.

Daniel, T. C. 2001. Whither scenic beauty? Visual landscape quality assessment in the 21 st century. Landscape and Urban Planning 54(1-4):267-281. http://dx.doi.org/10.1016/S0169-2046 (01)00141-4

de Groot, R. S., R. Alkemade, L. Braat, L. Hein, and L. Willemen. 2010. Challenges in integrating the concept of ecosystem services and values in landscape planning, management and decision making. Ecological Complexity 7(3):260-272. http://dx.doi. org/10.1016/j.ecocom.2009.10.006

de Groot, R. S., M. A. Wilson, and R. M. J. Boumans. 2002. A typology for the classification, description and valuation of ecosystem functions, goods and services. Ecological Economics 41(3):393-408. http://dx.doi.org/10.1016/S0921-8009(02)00089-7

DeLucio, J. V., and M. Múgica. 1994. Landscape preferences and behaviour of visitors to Spanish national parks. Landscape and Urban Planning 29(2-3):145-160. http://dx.doi.org/10.1016/0169-2046 (94)90024-8

Ericksen, P. J. 2008. What is the vulnerability of a food system to global environmental change? Ecology and Society 13(2): 14. [online] URL: http://www.ecologyandsociety.org/voll3/iss2/ $\underline{\operatorname{art} 14 /}$

Falk, J. H., and J. D. Balling. 2010. Evolutionary influence on human landscape preference. Environment and Behavior 42 (4):479-493. http://dx.doi.org/10.1177/0013916509341244

Farina, A. 2000.The cultural landscape as a model for the integration of ecology and economics. Bioscience 50(4):313-320. http://dx.doi.org/10.1641/0006-3568(2000)050[0313:TCLAAM]2.3. $\underline{\mathrm{CO}: 2}$

Fisher, B., R. K. Turner, and P. Morling. 2009. Defining and classifying ecosystem services for decision making. Ecological Economics 68(3):643-653. http://dx.doi.org/10.1016/j.ecolecon.2008.09.014

Foley, J. A., R. DeFries, G. P. Asner, C. Barford, G. Bonan, S. R. Carpenter, F. S. Chapin, M. T. Coe, G. C. Daily, H. K. Gibbs, J. H. Helkowski, T. Holloway, E. A. Howard, C. J. Kucharik, C. Monfreda, J. A. Patz, I. C. Prentice, N. Ramankutty, and P. K. Snyder. 2005. Global consequences of land use. Science 309 (5734):570-574. http://dx.doi.org/10.1126/science.1111772

Fry, G., M. S. Tveit, Å. Ode, and M. D. Velarde. 2009. The ecology of visual landscapes: exploring the conceptual common ground of visual and ecological landscape indicators. Ecological Indicators 9(5):933-947. http://dx.doi.org/10.1016/j.ecolind.2008.11.008

García-Llorente, M., B. Martín-López, I. Iniesta-Arandia, C. A. López-Santiago, P. A. Aguilera, and C. Montes. 2012. The role of multi-functionality in social preferences toward semi-arid rural landscapes: an ecosystem service approach. Environmental Science \& Policy 19-20:136-146. http://dx.doi.org/10.1016/j. envsci.2012.01.006

Gobster, P. H., J. I. Nassauer, T. C. Daniel, and G. Fry. 2007. The shared landscape: what does aesthetics have to do with ecology? Landscape Ecology 22(7):959-972. http://dx.doi.org/10.1007/ s10980-007-9110-X

González-Bernáldez, F. 1981. Ecología y paisaje. H. Blume, Barcelona, Spain.

González-Bernález, F., and F. Parra. 1979. Dimensions of landscape preferences from pairwise comparisons. Pages 256-262 in G. H. Elsner, editor. Proceedings of our national landscape: a conference on applied techniques for analysis and management of the visual resource. General Technical Report PSW-35. U.S. Forest Service, Pacific Southwest Forest and Range Experiment Station, Berkeley, California, USA. 
Gordon, L. J., C. M. Finlayson, and M. Falkenmark. 2010. Managing water in agriculture for food production and other ecosystem services. Agricultural Water Management 97 (4):512-519. http://dx.doi.org/10.1016/j.agwat.2009.03.017

Harper, D. 2002. Talking about pictures: a case for photoelicitation. Visual Studies 17(1):13-26. http://dx.doi. org/10.1080/14725860220137345

Harrison, P. A., M. Vandewalle, M. T. Sykes, P. M. Berry, R. Bugter, F. Bello, C. K. Feld, U. Grandin, R. Harrington, J. Haslett, R. H. G. Jongman, G. W. Luck, P. M. Silva, M. Moora, J. Settele, J. P. Sousa, and M. Zobel. 2010. Identifying and prioritising services in European terrestrial and freshwater ecosystems. Biodiversity and Conservation 19(10):2791-2821. http://dx.doi. org/10.1007/s10531-010-9789-X

Hartter, J. 2010. Resource use and ecosystem services in a forest park landscape. Society \& Natural Resources: An International Journal 23(3):207-223. http://dx.doi.org/10.1080/08941920903360372

Herzog, F., R. G. H. Bunce, M. Pérez-Soba, R. H. G. Jongman, A. Gómez-Sal, and I. Austad. 2005. Policy options to support transhumance and biodiversity in European mountains: a report on the TRANSHUMOUNT Stakeholder Workshop, Landquart/ Zurich, Switzerland, 26-28 May 2004. Mountain Research and Development 25(1):82-84. http://dx.doi.org/10.1659/0276-4741 (2005)025[0082:POTSTA]2.0.CO;2

Hicks, C. C., T. R. McClanahan, J. E. Cinner, and J. M. Hills. 2009. Trade-offs in values assigned to ecological goods and services associated with different coral reef management strategies. Ecology and Society 14(1): 10. [online] URL: http:// www.ecologyandsociety.org/vol14/iss1/art10/

Iftekhar, M. S., and T. Takama. 2008. Perceptions of biodiversity, environmental services, and conservation of planted mangroves: a case study on Nijhum Dwip Island, Bangladesh. Wetlands Ecology and Management 16(2):119-137. http://dx.doi.org/10.1007/ $\underline{\text { s11273-007-9060-8 }}$

Jorgensen, B. S., and R. C. Steadman. 2001. Sense of place as an attitude: lakeshore owners attitudes toward their properties. Journal of Environmental Psychology 21(3):233-248. http://dx.doi. org/10.1006/jevp.2001.0226

Kaltenborn, B. P., and T. Bjerke. 2002. Associations between environmental value orientations and landscape preferences. Landscape and Urban Planning 59(1):1-11. http://dx.doi. org/10.1016/S0169-2046(01)00243-2

Kaplan, S. 1987. Aesthetics, affect, and cognition: environmental preferences from an evoluntionary perspective. Environment and Behavior 19(1):3-32. http://dx.doi.org/10.1177/0013916587191001

Lamarque, P., U. Tappeiner, C. Turner, M. Steinbacher, R. D. Bardgett, U. Szukics, M. Schermer, and S. Lavorel. 2011. Stakeholder perceptions of grassland ecosystem services in relation to knowledge on soil fertility and biodiversity. Regional Environmental Change 11(4):791-804. http://dx.doi.org/10.1007/ s10113-011-0214-0

Larson, S., D. M. De Freitas, and C. C. Hicks. 2013. Sense of place as a determinant of peoples's attitude towards the environment: implications for natural resources management and planning in the Great Barrier Reef, Australia. Journal of
Environmental Management 117:226-234. http://dx.doi.org/10.1016/ j.jenvman.2012.11.035

Legendre, P., and L. Legendre, editors. 1998. Numerical ecology. Second English edition. Developments in environmental modelling. Volume 20. Elsevier, New York, New York, USA.

López-Santiago, C. 1994. Lo universal y lo cultural en la estética del paisaje. Un experimento transcultural de percepción del paisaje. Dissertation. Universidad Autónoma de Madrid, Madrid, Spain.

Manzano, P., and J. E. Malo. 2006. Extreme long-distance seed dispersal via sheep. Frontiers in Ecology and the Environment 4 (5):244-248. http://dx.doi.org/10.1890/1540-9295(2006)004[0244: ELSDVS]2.0.CO;2

Martín-López, B., E. Gómez-Bagghetun, M. García-Llorente, and C. Montes. 2014. Trade-offs across value-domains in ecosystem services assessments. Ecological Indicators 37 (A):220-228. http://dx.doi.org/10.1016/j.ecolind.2013.03.003

Martín-López, B., I. Iniesta-Arandia, M. García-Llorente, I. Palomo, I. Casado-Arzuaga, D. G. Del Amo, E. GómezBaggethun, E. Oteros-Rozas, I. Palacios-Agundez, B. Willaarts, J. A. González, F. Santos-Martín, M. Onaindia, C. LópezSantiago, and C. Montes. 2012. Uncovering ecosystem service bundles through social preferences. PLoS ONE 7(6):e38970. http://dx.doi.org/10.1371/journal.pone.0038970

Menzel, S., and J. Teng. 2010. Ecosystem services as a stakeholderdriven concept for conservation science. Conservation Biology 24 (3):907-909. http://dx.doi.org/10.1111/j.1523-1739.2009.01347.x

Merino, J., and J. L. Alier. 2004. La multifuncionalidad de las vías pecuarias españolas en el marco del desarrollo rural. Tecnología y Desarrollo 2:3-26.

Metzger, M. J., M. D. A. Rounsevell, L. Acosta-Michlik, R. Leemans, and D. Schröter. 2006. The vulnerability of ecosystem services to land use change. Agriculture, Ecosystems \& Environment 114(1):69-85. http://dx.doi.org/10.1016/j.agee.2005.11.025

Millennium Ecosystem Assessment. 2005. Ecosystems and human well-being: synthesis. Island Press, Washington D.C., USA.

Ministerio de Agricultura, Alimentación y Medio Ambiente. 2010. Programa de desarrollo rural sostenible. 1. Situación y diagnóstico del medio rural en España. Ministerio de Agricultura, Alimentación y Medio Ambiente, Gobierno de España, Madrid, Spain. http://www.magrama.gob.es/es/desarrollo-rural/temas/ igualdad_genero_y_des_sostenible/condiciones_vida_tcm7-9725. pdf

Ministerio de Medio Ambiente y Medio Rural y Marino. 2011. Diagnóstico de la igualdad de género en el medio rural. Ministerio de Medio Ambiente y Medio Rural y Marino, Madrid, Spain.

Montes, C., F. Santos-Martin, and J. Benayas, coordinators. 2011. Ecosistemas y biodiversidad para el bienestar humano. Evaluación de los ecosistemas del milenio de España [Spanish millennium ecosystem assessment]. Madrid, Spain, Fundación Biodiversidad, Ministerio de Medio Ambiente y Medio Rural y Marino.

Nieto-Romero, M., E. Oteros-Rozas, J. A. González, and B. Martín-López. 2014. Exploring the knowledge landscape of ecosystem services assessments in Mediterranean agroecosystems: 
insights for future research. Environmental Science \& Policy 37:121-133. http://dx.doi.org/10.1016/j.envsci.2013.09.003

Ornstein, R., L. L. Carstensen, and S. Patnoe. 1991. Psychology. The study of human experience. Third edition. Harcourt Brace Jovanovich, San Diego, California, USA.

Oteros-Rozas, E., J. A. González, B. Martín-López, C. A. López, and C. Montes. 2012a. Ecosystem services and social-ecological resilience in transhumance cultural landscapes: learning from the past, looking for a future. Pages 242-260 in T. Plieninger and C. Bieling, editors. Resilience and the cultural landscape: understanding and managing change in human-shaped environments. Cambridge University Press, Cambridge, UK. http://dx.doi.org/10.1017/CBO9781139107778.018

Oteros-Rozas, E., J. A. González, B. Martín-López, C. A. López, P. Zorrilla-Miras, and C. Montes. 2012b. Evaluating ecosystem services in transhumance cultural landscapes: an interdisciplinary and participatory framework. GAIA: Ecological Perspectives for Science \& Society 21(3):185-193.

Oteros-Rozas, E., B. Martín-López, J. A. González, T. Plieninger, C. A. López, and C. Montes. 2013. Socio-cultural valuation of ecosystem services in a transhumance social-ecological network. Regional Environmental Change December. http://dx.doi. org/10.1007/s10113-013-0571-y

Palomo, I., B. Martín-López, M. Potschin, R. Haines-Young, and C. Montes. 2013. National Parks, buffer zones and surrounding lands: mapping ecosystem service flows. Ecosystem Services 4:104-116. http://dx.doi.org/10.1016/j.ecoser.2012.09.001

Patton, M. Q. 1990. Qualitative evaluation and research methods. Second edition. Sage, Thousand Oaks, California, USA.

Plieninger, T., and C. Bieling. 2013. Resilience-based perspectives to guiding high-nature-value farmland through socioeconomic change. Ecology and Society 18(4): 20. http://dx.doi.org/10.5751/ ES-05877-180420

Plieninger, T., S. Dijks, E. Oteros-Rozas, and C. Bieling. 2013. Assessing, mapping, and quantifying cultural ecosystem services at community level. Land Use Policy 33:118-129. http://dx.doi. org/10.1016/j.landusepol.2012.12.013

Rao, C. R. 1964. The use and interpretation of principal component analysis in applied research. Sankhyâ: The Indian Journal of Statistics, Series A 26(4):329-358.

Raudsepp-Hearne, C., G. D. Peterson, and E. M. Bennett. 2010. Ecosystem service bundles for analyzing tradeoffs in diverse landscapes. Proceedings of the National Academy of Sciences of the United States of America 107(11):5242-5247. http://dx.doi. org/10.1073/pnas.0907284107

Ruiz, J. P., and F. González-Bernáldez. 1983. Landscape perception by its traditional users: the ideal landscape of Madrid livestock raisers. Landscape Planning 9:279-297. http://dx.doi. org/10.1016/0304-3924(83)90008-4

Ruiz, M., and J. P. Ruiz. 1986. Ecological history of transhumance in Spain. Biological Conservation 37(1):73-86. http://dx.doi. org/10.1016/0006-3207(86)90035-2
Schaich, H., C. Bieling, and T. Plieninger. 2010. Linking ecosystem services with cultural landscape research. GAIA: Ecological Perspectives for Science and Society 19(4):269-277.

Selman, P. 2012. Landscapes as integrating frameworks for human, environmental and policy processes. Pages 27-48 in $\mathrm{T}$. Plieninger and C. Bieling, editors. Resilience and the cultural landscape: understanding and managing change in human-shaped environments. Cambridge University Press, Cambridge, UK. http://dx.doi.org/10.1017/CBO9781139107778.004

Soini, K., H. Vaarala, and E. Pouta. 2012. Residents' sense of place and landscape perceptions at the rural-urban interface. Landscape and Urban Planning 104(1):124-134. http://dx.doi. org/10.1016/j.landurbplan.2011.10.002

Surová, D., and T. Pinto-Correia. 2008. Landscape preferences in the cork oak Montado region of Alentejo, southern Portugal: searching for valuable landscape characteristics for different user groups. Landscape Research 33(3):311-330. http://dx.doi. org/10.1080/01426390802045962

Swift, M. J., A.-M. N. Izac, and M. van Noordwijk. 2004. Biodiversity and ecosystem services in agricultural landscapesare we asking the right questions? Agriculture, Ecosystems \& Environment 104(1):113-134. http://dx.doi.org/10.1016/j.agee.2004.01.013

Tuan, Y.-F. 1974. Topophilia: a study of environmental perception, attitudes, and values. Columbia University Press, New York, New York, USA.

Ulrich, R. S. 1986. Human responses to vegetation and landscapes. Landscape and Urban Planning 13:29-44. http://dx. doi.org/10.1016/0169-2046(86)90005-8

Ulrich, R. S. 1990. The role of trees in human well-being and health. Pages 25-30 in P. Rodbell, editor. Proceedings of the Fourth Urban Forestry Conference. St. Louis, Missouri, USA.

Ulrich, R. S. 1995. Biophilia, biophobia, and natural landscapes. Pages 74-137 in S. A. Kellert and E. O. Wilson, editors. The biophilia hypothesis. Island Press/Shearwater, Washington, D.C., USA.

Van den Berg, A. E., C. A. J. Vlek, and J. F. Coeterier. 1998. Group differences in the aesthetic evaluation of nature development plans: a multilevel approach. Journal of Environmental Psychology 18(2):141-157. http://dx.doi.org/10.1006/jevp.1998.0080

Vihervaara, P., M. Rönkä, and M. Walls. 2010. Trends in ecosystem service research: early steps and current drivers. Ambio 39(4):314-324. http://dx.doi.org/10.1007/s13280-010-0048-x

Yu, K. 1995. Cultural variations in landscape preference: comparisons among Chinese sub-groups and Western design experts. Landscape and Urban Planning 32(2):107-126. http://dx. doi.org/10.1016/0169-2046(94)00188-9 
APPENDIX 1. Description of the variables used in the study.

\begin{tabular}{|c|c|c|c|c|c|}
\hline Quantitative variables & Type & \multicolumn{2}{|l|}{ Attributes } & Mean & Std. deviation \\
\hline Education Level & ordinal & \multicolumn{2}{|c|}{1 primary; 2 secondary; 3 university } & 2.083 & 0.834 \\
\hline Visit frequency & ordinal & \multicolumn{2}{|c|}{0 never; 1 yearly; 2 monthly; 3 weekly } & 1.374 & 0.795 \\
\hline Environmental reader & ordinal & \multicolumn{2}{|c|}{0 never; 1 yearly; 2 monthly; 3 weekly } & 0.754 & 0.956 \\
\hline Age & continuous & \multicolumn{2}{|c|}{$\ln ($ age $)$} & 3.551 & 0.395 \\
\hline Qualitative variables & Type & Categories & Attributes & Frequency & Percentage (\%) \\
\hline \multirow{2}{*}{ La Mancha residents } & \multirow{2}{*}{ binary } & 0 & Not resident in La Mancha cropland cultural landscape & 277 & 88 \\
\hline & & 1 & Resident in La Mancha cropland cultural landscape & 37 & 12 \\
\hline \multirow{3}{*}{ Serranía residents } & \multirow{3}{*}{ binary } & 0 & Not resident in Cuenca pine forest cultural landscape & 185 & 59 \\
\hline & & 1 & Resident in Cuenca pine forest cultural landscape & 129 & 41 \\
\hline & & Rural & Less than 2.000 inhabitants & 103 & 33 \\
\hline \multirow[t]{2}{*}{ Degree of rurality of respondents } & \multirow[t]{2}{*}{ categorical } & Semirural & Between 2.000 and 30.000inhabitants & 56 & 18 \\
\hline & & Urban & More than 30.000 inhabitants & 155 & 49 \\
\hline \multirow{2}{*}{ Feeling of being rural } & \multirow{2}{*}{ binary } & 0 & The informant does not feel that they have a rural lifestyle and worldview & 97 & 31 \\
\hline & & 1 & The informant feels that they have a rural lifestyle and worldview & 217 & 69 \\
\hline \multirow{2}{*}{ Experience with transhumance } & \multirow{2}{*}{ binary } & 0 & The informant does not report previous experience with transhumance or herders & 202 & 64 \\
\hline & & 1 & The informant reports previous experience with transhumance or herders & 112 & 36 \\
\hline \multirow{2}{*}{ Gender } & \multirow{2}{*}{ categorical } & Male & & 176 & 56 \\
\hline & & Female & & 138 & 44 \\
\hline \multirow{2}{*}{ Formal environmental education } & \multirow{2}{*}{ binary } & 0 & The informant was not formally educated and/or trained in environmental sciences or arts and crafts & 235 & 75 \\
\hline & & 1 & The informant was formally educated and/or trained in environmental sciences & 79 & 25 \\
\hline \multirow{2}{*}{ Herders } & \multirow{2}{*}{ binary } & 0 & The informant does not work as a pastoralist & 260 & 83 \\
\hline & & 1 & The informant works as a pastoralist & 54 & 17 \\
\hline \multirow{2}{*}{ Farmers } & \multirow{2}{*}{ binary } & 0 & The informant does not work as peasant or farmer & 250 & 80 \\
\hline & & 1 & The informant works as peasant or farmer & 64 & 20 \\
\hline \multirow{2}{*}{ Drove road preference } & \multirow{2}{*}{ binary } & 0 & The informant chose the image without a drove road & 152 & 48 \\
\hline & & 1 & The informant chose the image with a drove road & 162 & 52 \\
\hline
\end{tabular}




\section{APPENDIX 2.}

Ecosystem services explored: descriptions, examples and correspondence classification according to Millennium Assessment (based in de Groot et al., 2002; Oteros-Rozas et al., 2012).

\begin{tabular}{|c|c|c|c|c|}
\hline Type of ES & $\begin{array}{l}\text { Ecosystem } \\
\text { services }\end{array}$ & Description & Examples & MA \\
\hline \multirow[t]{5}{*}{ Provisioning } & Gathering & $\begin{array}{l}\text { Mushrooms and wild edible } \\
\text { plants and }\end{array}$ & $\begin{array}{l}\text { Asparagus, } \\
\text { Boletus eduli }\end{array}$ & Food \\
\hline & Feed for animals & Cereal crops for animal feeding & Barley, stubble & Food \\
\hline & $\begin{array}{l}\text { Food from } \\
\text { agriculture }\end{array}$ & Crops for human consumption & Olives, wine & Food \\
\hline & Wood and timber & $\begin{array}{l}\text { Forest products used as fuel or as } \\
\text { building materials }\end{array}$ & Pine timber & Fuel / Fibre \\
\hline & Livestock & Food from livestock & Lamb, veal & Food \\
\hline \multirow[t]{6}{*}{ Regulating } & Plant regeneration & $\begin{array}{l}\text { Influence of temporal and low } \\
\text { stocking grazing (transhumance) } \\
\text { in plant regeneration, by } \\
\text { facilitating seeds germination }\end{array}$ & $\begin{array}{l}\text { Pines' } \\
\text { regeneration }\end{array}$ & - \\
\hline & Air purification & $\begin{array}{l}\text { Role of ecosystems in bio- } \\
\text { geochemical cycles }\end{array}$ & Clean air & $\begin{array}{l}\text { Air quality } \\
\text { regulation }\end{array}$ \\
\hline & Habitat for species & $\begin{array}{l}\text { Provision of suitable living and } \\
\text { nursery places for wild species }\end{array}$ & Rabbits, birds & $\begin{array}{l}\text { Provision of } \\
\text { habitat }\end{array}$ \\
\hline & Fire prevention & $\begin{array}{l}\text { Influence of ecosystems' } \\
\text { functioning on reducing } \\
\text { frequency and extension of fire } \\
\text { events }\end{array}$ & $\begin{array}{l}\text { Consumption of } \\
\text { inflammable } \\
\text { biomass by } \\
\text { herbivores }\end{array}$ & $\begin{array}{l}\text { Natural hazard } \\
\text { regulation }\end{array}$ \\
\hline & $\begin{array}{l}\text { Soil erosion } \\
\text { control }\end{array}$ & $\begin{array}{l}\text { Role of the root systems and soil } \\
\text { biota in soil retention }\end{array}$ & $\begin{array}{l}\text { Retention of soil } \\
\text { by roots }\end{array}$ & $\begin{array}{l}\text { Erosion } \\
\text { regulation }\end{array}$ \\
\hline & Connectivity & $\begin{array}{l}\text { Role of ecosystems' structure for } \\
\text { allowing animal and plant } \\
\text { movement and colonisation }\end{array}$ & $\begin{array}{l}\text { Dispersal of } \\
\text { pasture species }\end{array}$ & Seed dispersal \\
\hline \multirow[t]{5}{*}{ Cultural } & $\begin{array}{l}\text { Tranquillity/ } \\
\text { relaxation }\end{array}$ & $\begin{array}{l}\text { Influence of ecosystems in } \\
\text { human physical and } \\
\text { psychological well-being by } \\
\text { relaxation }\end{array}$ & $\begin{array}{l}\text { Pleasure of } \\
\text { walking in the } \\
\text { woods }\end{array}$ & $\begin{array}{l}\text { Aesthetic } \\
\text { values / } \\
\text { Inspiration }\end{array}$ \\
\hline & Tourism & $\begin{array}{l}\text { Influence of ecosystem in human } \\
\text { well-being through recreational } \\
\text { activities }\end{array}$ & $\begin{array}{l}\text { Horse-riding, } \\
\text { cycling, hiking }\end{array}$ & $\begin{array}{l}\text { Recreation and } \\
\text { ecotourism }\end{array}$ \\
\hline & Cultural identity & $\begin{array}{l}\text { Variety of natural features that } \\
\text { embody or reinforce cultural } \\
\text { values }\end{array}$ & $\begin{array}{l}\text { Music, pictures, } \\
\text { symbols }\end{array}$ & $\begin{array}{l}\text { Cultural } \\
\text { diversity }\end{array}$ \\
\hline & Hunting & Leisure activity of hunting & Rabbit, partridge & $\begin{array}{l}\text { Recreation and } \\
\text { ecotourism }\end{array}$ \\
\hline & Aesthetic value & Attractive landscape features & $\begin{array}{l}\text { Pleasure of a } \\
\text { beautiful view }\end{array}$ & $\begin{array}{l}\text { Aesthetic } \\
\text { values }\end{array}$ \\
\hline
\end{tabular}

